4. Ross PJ, Jacobson J, Muir JR. Q fever endocarditis of porcine xenograft valves. Am Heart J. 1983;105:151-3. http://dx.doi. org/10.1016/0002-8703(83)90293-4

5. al-Hajjar S, Hussain Qadri SM, al-Sabban E, Jager C. Coxiella burnetii endocarditis in a child. Pediatr Infect Dis J. 1997;16:911-3. http://dx.doi. org/10.1097/00006454-199709000-00020

6. Saginur R, Silver SS, Bonin R, Carlier M, Orizaga M. Q-fever endocarditis. CMAJ. 1985;133:1228-30.

7. Angelakis E, Richet H, Rolain JM, La SB, Raoult D. Comparison of real-time quantitative PCR and culture for the diagnosis of emerging rickettsioses. PLoS Negl Trop Dis. 2012;6:e1540.

8. Angelakis E, Million M, D'Amato F, Rouli L, Richet H, Stein A, et al. Q fever and pregnancy: disease, prevention, and strain specificity. Eur J Clin Microbiol Infect Dis. 2013;32:361-8.

9. Million M, Walter G, Bardin N, Camoin L, Giorgi R, Bongrand $\mathrm{P}$, et al. Immunoglobulin $\mathrm{G}$ anticardiolipin antibodies and progression to Q fever endocarditis. Clin Infect Dis. 2013;57:57-64. http://dx.doi. org/10.1093/cid/cit191

10. Hussein MF, Al-Khalifa IM, Aljumaah RS, Gar Elnabi A, Mohammed OB, Omer SA, et al. Serological prevalence of Coxiella burnetii in captive wild ruminants in Saudi Arabia. Comparative Clinical Pathology. 2012;21:33-8. http://dx.doi.org/10.1007/ s00580-010-1061-y

Address for correspondence: Didier Raoult, URMITE UMR 6236, CNRS-IRD, Faculté de Médecine, 27 Blvd Jean Moulin, 13385 Marseille Cedex 05, France; email: didier. raoult@gmail.com

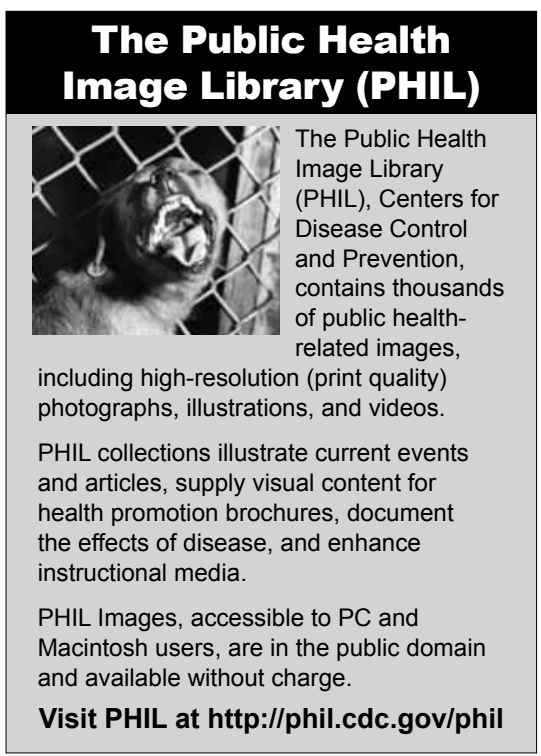

\section{Lack of MERS Coronavirus but Prevalence of Influenza Virus in French Pilgrims after 2013 Hajj}

To the Editor: Saudi Arabia has reported the highest number of Middle East respiratory syndrome coronavirus (MERS-CoV) cases since the virus first emerged in 2012, with $>127$ confirmed cases and a case-fatality rate of $42 \%$, as of November 2013 (1). Global attention has focused on the potential for spread of MERS-CoV after the Hajj pilgrimage during which Muslims from 180 countries converge in Mecca, Saudi Arabia. Such pilgrims have a high risk for respiratory tract infections because of severe overcrowding. The International Health Regulations Emergency Committee advised all countries (particularly those with returning pilgrims) to strengthen their surveillance capacities and ensure robust reporting of any identified cases (2).

We report the results of a prospective cohort study conducted in Saudi Arabia in October 2013. Participants in the survey were adult Hajj pilgrims who traveled together in a group (through 1 travel agency in Marseille, France) from October 3 through October 24, 2013. Pilgrims were included in the study on a voluntary basis and were asked to sign a written consent form. All pilgrims received advice about individual prevention measures against respiratory tract infection before departing, and follow-up was conducted during the journey by a medical doctor who systematically documented travel-associated diseases. Nasal swab specimens were obtained just before the pilgrims left Saudi Arabia, frozen $<48$ hours after sampling, and processed $(3,4)$. Each sample was tested for MERS-CoV (upE and ORF1a genes) $(5,6)$ and influenza A, B (7), and A/2009/H1N1 viruses $(8)$ by real-time reverse transcription PCR. The protocol was approved by our Institutional Review Board (July 23, 2013; reference no. 2013-A00961-44) and by the Saudi Ministry of Health ethics committee.

On departure from France, the study comprised 129 pilgrims. Their mean age was 61.7 years (range 34-85 years), and the male/female ratio was $0.7: 1$. Sixty-eight $(52.7 \%)$ pilgrims reported having a chronic disease, including hypertension (43 [33.3\%]), diabetes (34 [26.4\%]), chronic cardiac disease (11 [8.5\%]), and chronic respiratory disease (5 [3.9\%]). Forty-six $(35.7 \%)$ pilgrims reported receiving influenza vaccination in 2012; none had been vaccinated in 2013 before the Hajj because the vaccine was not yet available in France.

Clinical data were available for 129 persons: 117 (90.7\%) had respiratory symptoms while in Saudi Arabia, including cough (112 [86.8\%]) and sore throat (107 [82.9\%]); $64(49.6 \%)$ reported fever, and $61(47.3 \%)$ had conditions that met the criteria for influenza-like illness (ILI; i.e., the association of cough, sore throat, and subjective fever) (Figure) (4). One patient was hospitalized during travel (undocumented pneumonia). Nasal swab specimens were obtained from 129 pilgrims on October 23, 2013 (week 43), 1 day before pilgrims left Saudi Arabia for France; 90 (69.8\%) pilgrims were still symptomatic. All PCRs were negative for MERS-CoV.

Eight pilgrims tested positive for influenza $\mathrm{A}(\mathrm{H} 3 \mathrm{~N} 2), 1$ for influenza $\mathrm{A}(\mathrm{H} 1 \mathrm{~N} 1)$, and 1 for influenza $\mathrm{B}$ virus. No dual infections were reported. $70(54.3 \%)$ pilgrims were seen $3-5$ weeks after they returned to France, and the remaining were lost to followup. Fifty-five (78.6\%) had experienced respiratory symptoms since their return, including cough (50 [71.4\%]) and sore throat (14 [20.0\%]); $12(17.1 \%)$ reported fever, and illness in $5(7.1 \%)$ pilgrims met the criteria for ILI. The 10 pilgrims who had positive test 


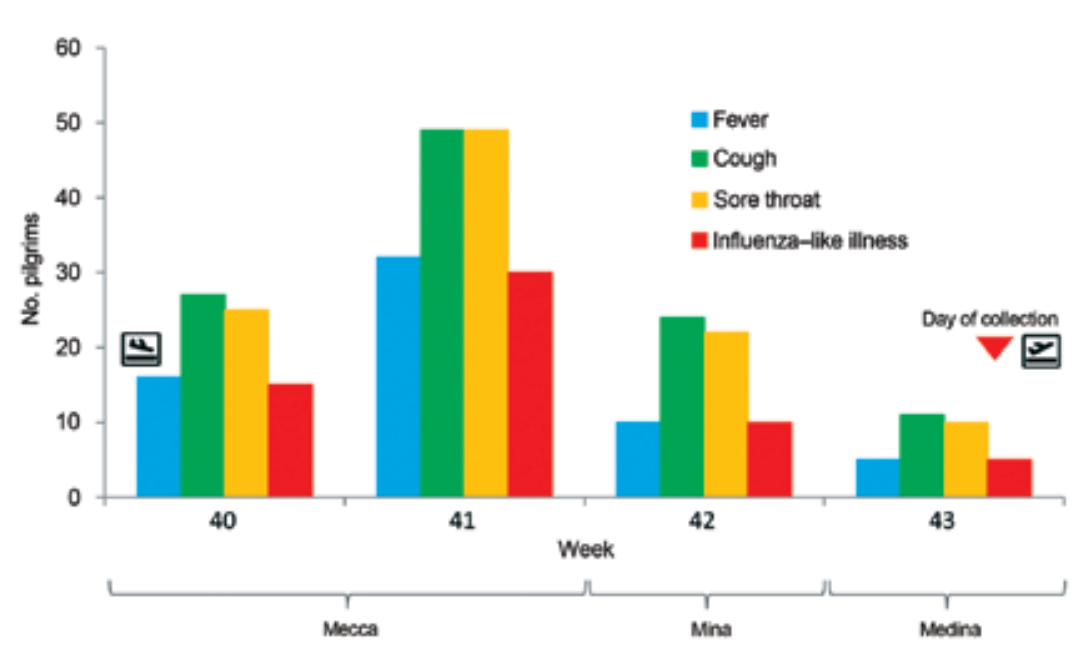

Figure. Onset of respiratory symptoms by week, reported by 129 Hajj pilgrims from France during their stay in Saudi Arabia, October 2013.

results for influenza virus on return had cleared their infection; only 1 additional sample was positive (for influenza $\mathrm{A}[\mathrm{H} 1 \mathrm{~N} 1])$.

Our results support data obtained from a similar cohort in 2012 that showed a lack of nasal carriage of MERS-CoV among Hajj pilgrims from France (3). However, a higher prevalence of influenza virus (7.8\%) was observed in nasal swab specimens in 2013 than in 2012 when $2(3.2 \%)$ cases of influenza $\mathrm{B}$ virus infection were detected and no case of influenza A virus infection was detected among 162 pilgrims returning from the Hajj (4).

The estimated incidence of ILI in France during week 43 was 27 per 100,000 inhabitants, far below the epidemic threshold $(126 / 100,000)$ with few sporadic cases of influenza A virus infection reported in some regions in France (www.grog.org/ bullhebdo_pdf/bull_grog_43-2013. pdf). No case was reported in the Marseille area (http://websenti.u707. jussieu.fr/sentiweb). The high prevalence of respiratory symptoms in our cohort probably reflects the close surveillance performed and is consistent with 2012 results $(3,4)$.

In Marseille, all patients with suspected MERS-CoV infection are referred to the Institut HospitaloAs of November 8, 2013, of the 14 first returning patients hospitalized for respiratory symptoms and screened for MERS-CoV and other pathogens, including influenza, 4 were infected with influenza $A(H 3 N 2), 4$ with influenza $A(H 1 N 1)$, and 1 with influenza $B$ virus. All samples tested negative for MERS-CoV.

Our preliminary results indicate that pilgrims from France returning from the 2013 Hajj were free of MERS-CoV but that a proportion were infected with influenza viruses and may represent a potential for early introduction of influenza in southern France. This proportion may have been underestimated because screenstudy period when some infections had cleared. Influenza vaccination should be a priority for pilgrims attending the Hajj $(9,10)$.

\section{Acknowledgments}

We thank Nadia Saidani, the clinical doctors, and the pilgrims, whose support and participation made this project successful.

\section{Philippe Gautret, Rémi Charrel, Samir Benkouiten, Khadidja Belhouchat,}

Universitaire Méditerranée Infection. ing was performed at the end of the

\section{Antoine Nougairede, Tassadit Drali, Nicolas Salez, Ziad A. Memish, Malak al Masri, Jean-Christophe Lagier, Matthieu Million, Didier Raoult, Philippe Brouqui, and Philippe Parola}

Author affiliations: Aix Marseille Université, Marseille, France (P. Gautret, R. Charrel, S. Benkouiten, A. Nougairde, N. Salez, J.C. Lagier, M. Million, D. Raoult, P. Brouqui, P. Parola); Institut Hospitalo-Universitaire Méditerranée Infection, Marseille (P. Gautret, R. Charrel, S. Benkouiten, K. Belhouchat, A. Nougairede, T. Drali, N. Salez, J.-C. Lagier, M. Million, D. Raoult, P. Brouqui, P. Parola); Public Health Directorate, Saudi Ministry of Health, Riyadh, Kingdom of Saudi Arabia (Z.A. Memish, M. al Masri); and College of Medicine, Alfaisal University, Riyadh (A. Memish)

DOI: http://dx.doi.org/10.3201/eid2004.131708

\section{References}

1. Memish ZA, Al-Tawfiq JA, Al-Rabeeha AA. Hajj: preparations underway. Lancet Glob Health. 2013;1:e331. http://dx.doi. org/10.1016/S2214-109X(13)70079-2

2. World Health Organization. WHO Statement on the third meeting of the IHR Emergency committee concerning Middle East respiratory syndrome coronavirus (MERS-CoV). Wkly Epidemiol Rec. 2013;88:435-6.

3. Gautret P, Charrel R, Belhouchat K, Drali T, Benkouiten S, Nougairede A, et al. Lack of nasal carriage of novel corona virus (HCoV-EMC) in French Hajj pilgrims returning from the Hajj 2012, despite a high rate of respiratory symptoms. Clin Microbiol Infect. 2013;19:E315-7. http://dx.doi.org/10.1111/1469-0691.12174

4. Benkouiten S, Charrel R, Belhouchat K, Drali T, Salez N, Nougairede A, et al. Circulation of respiratory viruses among pilgrims during the 2012 Hajj pilgrimage. Clin Infect Dis. 2013;57:992-1000. http:// dx.doi.org/10.1093/cid/cit446

5. Corman VM, Müller MA, Costabel U, Timm J, Binger T, Meyer B, et al. Assays for laboratory confirmation of novel human coronavirus (hCoV-EMC) infections. Euro Surveill. 2012;17:20334.

6. Corman VM, Eckerle I, Bleicker T, Zaki A, Landt O, Eschbach-Bludau M, et al. Detection of a novel human coronavirus by real-time reverse-transcription 
polymerase chain reaction. [Erratum in: Euro Surveill. 2012;17: pii/20288]. Euro Surveill. 2012;17:20285.

7. van Elden LJ, Nijhuis M, Schipper P, Schuurman R, van Loon AM. Simultaneous detection of influenza viruses $A$ and $\mathrm{B}$ using real-time quantitative PCR. J Clin Microbiol. 2001;39:196-200. http://dx.doi.org/10.1128/JCM.39.1.196200.2001

8. Duchamp MB, Casalegno JS, Gillet Y, Frobert E, Bernard E, Escuret V, et al. Pandemic A(H1N1)2009 influenza virus detection by real time RT-PCR: is viral quantification useful? Clin Microbiol Infect. 2010;16:317-21. http://dx.doi. org/10.1111/j.1469-0691.2010.03169.x

9. World Health Organization. Health conditions for travellers to Saudi Arabia for the pilgrimage to Mecca (Hajj). Wkly Epidemiol Rec. 2013;88:343-7.

10. Haworth E, Barasheed O, Memish ZA, Rashid H, Booy R. Prevention of influenza at Hajj: applications for mass gatherings. J R Soc Med. 2013;106:215-23. http:// dx.doi.org/10.1258/jrsm.2012.120170

Address for correspondence: Philippe Gautret, Aix Marseille Université, URMITE, 27 Bd Jean Moulin, 13005 Marseille, France; email: philippe.gautret@club-internet.fr

\section{St. Louis Encephalitis Virus Infection in Woman, Peru}

To the Editor: St. Louis encephalitis virus (SLEV) is a flavivirus that can asymptomatically infect humans or cause clinically apparent disease that manifests with fever, headache, nausea, and vomiting (1). More severe disease with meningoencephalitic involvement may result in stiff neck, alteration in consciousness, gait disturbance, and other focal neurologic deficits. Heightened levels of human disease are often associated with increased abundance of Culex spp. mosquitoes and the summer season.
SLEV was first reported in South America in 1960, when it was isolated from pools of Sabethes bellisarioi mosquitoes and Gigantolaelaps mites in Pará, Brazil (2). SLEV was later recovered from humans in Argentina (1963) (3) and Brazil (1978) (4). Sporadic infections and large outbreaks occurred over ensuing decades, although no isolates in humans have been reported in other South American countries.

Serologic indication of SLEV circulation in Peru was first obtained from hemagglutination-inhibition and neutralization tests of samples collected in 1965 from residents of eastern Peru (5). Later, SLEV was isolated from mosquitoes $(6,7)$, and SLEV antibody was detected in serum specimens from humans by plaque reduction neutralization tests (6). We report the isolation of SLEV from a person in Peru and describe a unique collection method, using oropharyngeal swab specimens, for detecting this virus.

In March 2006, a 50-year-old woman with a 1-day history of fever, sore throat, cough, malaise, myalgia, and headache sought treatment at her local health center in Quistococha, Peru, in the Amazon Basin ( $3^{\circ} 49^{\prime} 40^{\prime \prime}$ $\mathrm{N} ; 73^{\circ} 19^{\prime} 6^{\prime \prime}$ E). The woman's recent travel was limited to a $70-\mathrm{km}$ radius from this town. Because influenza was suspected, an oropharyngeal swab specimen was collected as part of an influenza-like illness surveillance project, which had been approved by the US Naval Medical Research Center Institutional Review Board and endorsed by the Peruvian Ministry of Health. No blood specimen was obtained because blood was not collected in this respiratory infection-focused protocol. The swab specimen was inoculated onto Madin-Darby canine kidney cells; no cytopathic effect was observed, and the culture was negative for influenza virus and for other respiratory viruses amenable to culture (e.g., adenovirus and parainfluenza virus).
Nearly 6 years later, as part of a retrospective study of previously negative respiratory specimens, the sample was reevaluated for arboviral infection. Universal transport medium (Copan Diagnostics Inc., Murrieta, CA, USA), containing the swab specimen, was inoculated onto Vero 76 cells; cytopathic effects were revealed on day 7. The cells were harvested, and an indirect immunofluorescence assay was performed by using a panel of mouse polyclonal hyperimmune ascitic fluid specific to a variety of flaviviruses. The initial screening tests indicated reactivity to yellow fever virus, dengue virus, and SLEV. Subsequent immunofluorescence assay analyses using monoclonal antibodies against yellow fever virus and all 4 dengue virus serotypes were negative.

Viral RNA was recovered from the Vero culture supernatant and amplified by conventional reverse transcription PCR/nested PCR with generic flavivirus primers against the nonstructural 5 coding region, which confirmed that the isolate was a flavivirus. Real-time reverse transcription PCR with specific SLEV primers confirmed SLEV.

A total of $10,850 \mathrm{bp}$, almost the full genome sequence of the virus, were sequenced (GenBank accession no. KF589299), and 10,236 nt from these sequences were compared with other SLEV sequences in GenBank. The strain showed $98.4 \%$ similarity with a SLEV strain isolated from a bird in Brazil in 1973, 98.4\% similarity with an SLEV strain isolated from mosquitoes in Peru in 1975, and 97.9\% similarity with an SLEV strain isolated from mosquitoes in the United States in 2003. The US strain may have been carried by migratory birds from Latin America (8). Phylogenetic analysis by the neighbor-joining method with 1,000 bootstraps replicates identified the isolate as genotype $\mathrm{V}$, subgenotype A, which grouped with the strains obtained in Brazil, Peru, and the United States (Figure) and 